\title{
Industrial surfacing and hardfacing technology, fundamentals and applications
}

\author{
Andrzej Klimpel ${ }^{1, *}$ \\ 1 Silesian University of Technology, Poland \\ * Correspondence: prof. Andrzej Klimpel; andrzej.klimpel@polsl.pl
}

\begin{abstract}
The technological fundamentals of modern processes of production surfacing and regeneration of machine parts and equipment as well as methods of assessment of properties and quality of deposits are described. Examples of industrial applications of oxy-acetylen gas, MMA, GMA, SSAW, GTA, PTA, SA and laser surfacing and hardfacing are presented.
\end{abstract}

Keywords: hardfacing technologies; remanufacturing, surface modification

\section{Introduction}

Surfacing technologies are developed in the world industry in parallel with welding technologies, usually as modifications of these technologies. Probably for this reason, surfacing technologies were treated, especially in the early stages of development and sometimes are still as "inferior" - requiring less research effort. There are still no normative studies in the field of quality assurance systems for welded production layers, especially regenerative ones.

In order to increase the durability of machine and device parts, and at the same time to save costs and to a certain extent protect the environment, production and regenerative (repair) surfacing technologies are increasingly used in the global industry [1:18]. The parallel development of research into the functional properties of surface layers and modern welding materials provides the opportunity to develop production and/or regenerative surfacing technologies, ensuring significantly higher performance properties and high economic efficiency, especially in the case of developing multiple regeneration technological conditions.

Professor Józef Pilarczyk, already in the 1960s implemented regenerative and then production surfacing technologies, unfortunately with very limited interest of the Polish industry, not very aware of the useful and economic advantages of surfacing technologies. Currently, surfacing technologies are a very important field of welding engineering, in which laser technologies of surfacing, alloying or remelting the surface layer are particularly interesting [11].

The world industry places higher and higher requirements regarding the operating parameters of machinery and equipment parts, while also expecting the highest possible technical and economic effects. Thus, designers and technologists involved in the design and manufacture of modern machinery and equipment must take into account the issues of operational durability and economy $[1,7 \div 12]$. Meeting these conditions requires the use of modern computer-aided design methods and in-depth knowledge of material engineering. The very dynamic development of material engineering in recent years, including metallurgy and welding technologies, in particular laser technologies, ensures that designers of modern machinery and equipment parts have increasingly better engineering materials at their disposal, ensuring previously unattainable usability, as in the case of nanostructured materials or nanotubes and graphene $[7,8]$.

On the other hand, knowledge about the properties and scope of applications of metal, ceramic and cermet materials can only be used provided that the surfacing processes are well known. Surfacing technologies are used to regenerate (repair) worn parts of machinery and equipment and as part of the production process of new products (production surfacing), followed by their planned regeneration, and these processes can be carried out manually, semi-automatically, automatically or in a robotic manner, in workshop and assembly conditions. It is possible to apply coatings from virtually any engineering materials with a thickness from hundredths of a millimeter (laser surfacing) to several dozen millimeters, with a capacity of over $100 \mathrm{~kg} / \mathrm{h}$ (submerged arc welding, explosive surfacing) [9,10]. 


\section{Tribological, metallurgical and technological basics of the surfacing processes}

The basic task of modern technologies of surfacing the surface layers of machinery and equipment parts is to ensure the highest possible operational properties, and at the same time the highest possible economic effects $[1 \div 18]$. The criteria for assessing the operational properties of surface layers depend on the operating conditions of machine and equipment parts, which form the basis of design parameters for shape and dimensions, and strictly with this related selection of material. The task of the designer is to develop such a construction solution that ensures the maximum physically possible durability of the parts (minimum wear) at the lowest possible manufacturing costs. The durability of parts in most cases is determined by the tribological properties of the working surface layers - excessive wear causes that the parts are scrapped or subjected to regeneration processes [1.9 $\div 18]$.

The wear of machine parts and devices is defined as a decrease in the usability of the working surface and can be caused by many different physical and chemical processes occurring during the operation process. The wear of the working surface of the part entails a decrease in its performance. Wear mechanisms are very complex and contain many interrelated factors, the most important of which are as follows $[1 \div 6,9,11,12]$ :

- type and amount of mechanical load,

- slip speed of friction working surfaces (surface layers),

- working temperature of the construction,

- hardness and structure of friction working surfaces,

- condition (smoothness) of the working surface,

- corrosive environment,

- type of abradant,

- friction coefficient of working surfaces,

- duration of the wear process.

Most often, the working surfaces of machinery and equipment parts are subject to wear as a result of a separate or combined action:

- friction processes: abrasive wear and adhesive wear (tribological wear),

- shock load,

- erosion and cavitation,

- high temperature,

- corrosion.

The simplest indicator of wear is the loss of material of the working layer of machine and equipment parts (padding welds), resulting mainly from friction, corrosion or cracking of the surface layer. An analysis of the reasons for the wear of machine parts and devices shows that about $50 \%$ of the parts undergo abrasive wear, $15 \%$, adhesive wear, $8 \%$ erosion, $8 \%$ fretting, $5 \%$ wear as a result of corrosion and about $14 \%$ of the total impact, e.g. corrosion, erosion and abrasion $[1 \div 7,9]$. In order to rationally select additional materials and determine the technological conditions for applying coatings, ensuring maximum durability of the surfaced or thermally sprayed object with minimal costs, it is necessary to understand the individual phenomena accompanying each of these wear processes, which are served by various types of non-destructive and destructive tests [1]. The basic methods of testing for wear resistance, which are also part of the quality assessment of padding welds are hardness measurements, metal-to-metal and ceramicmetal abrasive wear tests, impact load tests, metallographic, ultrasonic, penetration tests and tests of

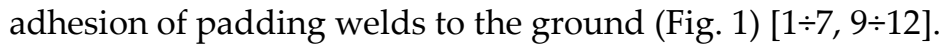
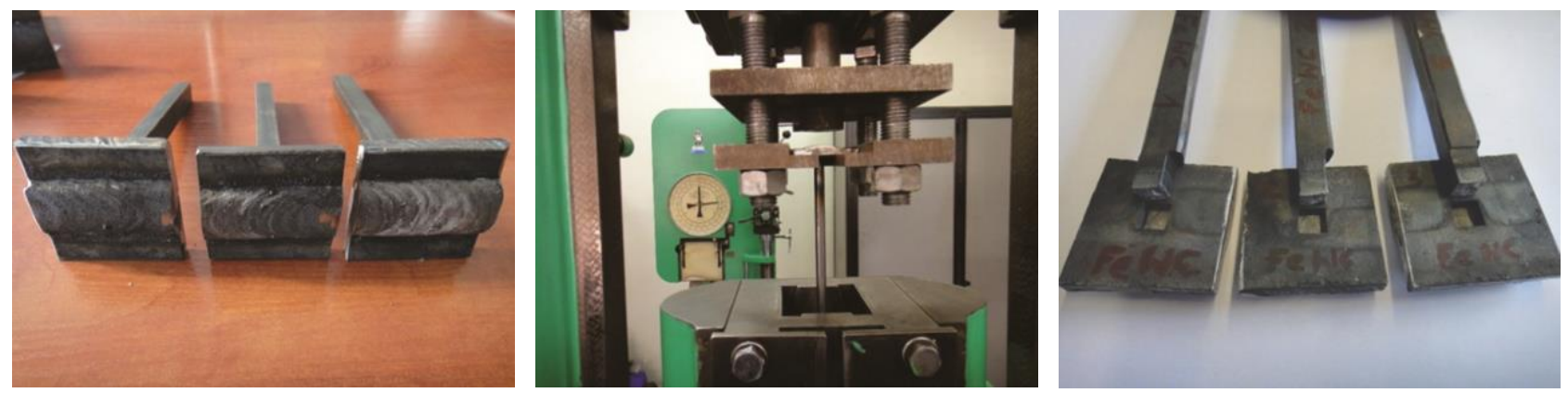

Fig. 1. A view of the specimen and a run of tests of adherence of GMA deposits of nano-structural Corodur 717-B solid wire to ARMOX 500 base metal [5,9] 
The process of determining the required operational properties of the surface layer must be based on accurate knowledge of the working conditions of the surfaced or thermally sprayed object. The main reasons for the wear of the items described above clearly indicate that the assessment of the functional properties of the surface layer material cannot be made solely on the basis of one, most commonly used parameter - hardness. Metal materials of similar hardness but with different structure show significant differences in resistance to abrasive wear under low and high loads, or adhesive wear (Figs. 2 and 3).

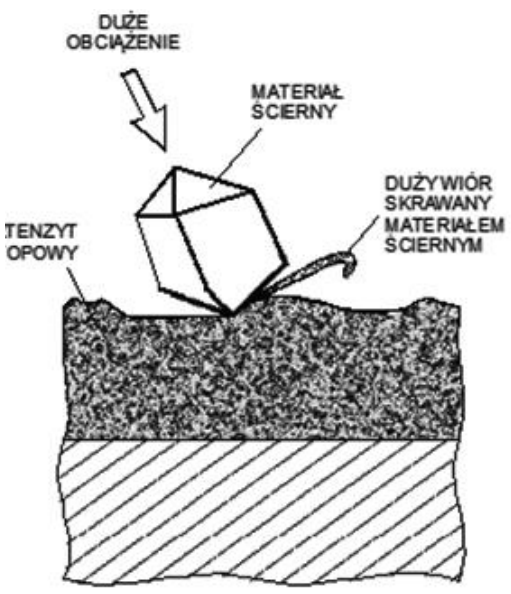

(a)

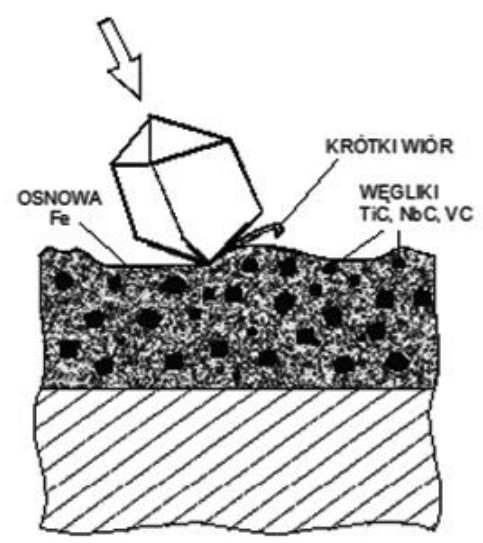

(b)

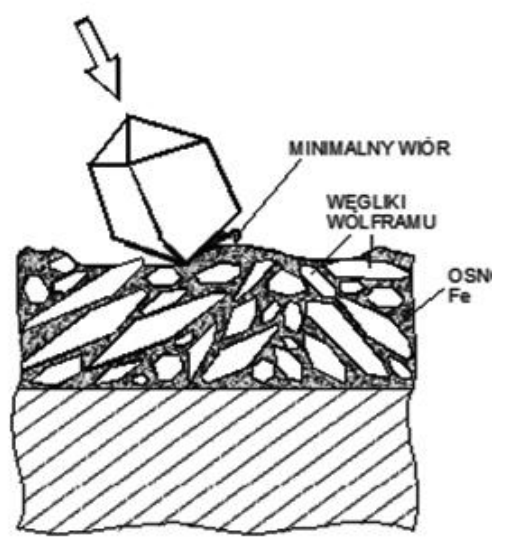

(c)

Fig. 2. Comparison of a wear resistance at high loads of deposits surfaced from materials (consumables) of a different structure and similar hardness: a) the deposit of martensitic chromium steel containing: 0,5 $\div 0,65 \% \mathrm{C}, 1,4-6,0 \% \mathrm{Mo}$, $1,6 \div 1,8 \% \mathrm{~W}, 1,1 \% \mathrm{~V}$ and hardness $53-60 \mathrm{HRC}, \mathrm{b})$ the deposit of hypereutectoid cast iron containing: 5,0 $\div 5,5 \% \mathrm{C}$, $15 \div 20 \% \mathrm{Cr}, 5,0 \% \mathrm{Mo}+\mathrm{Ti}+\mathrm{Nb}+\mathrm{V}$ and small carbides of hardness 55-60 HRC, c) the cermetalic deposit containing $65 \% \mathrm{WC}$ in iron matrix - average hardness of the deposit approx. $60 \mathrm{HRC}$ [9]

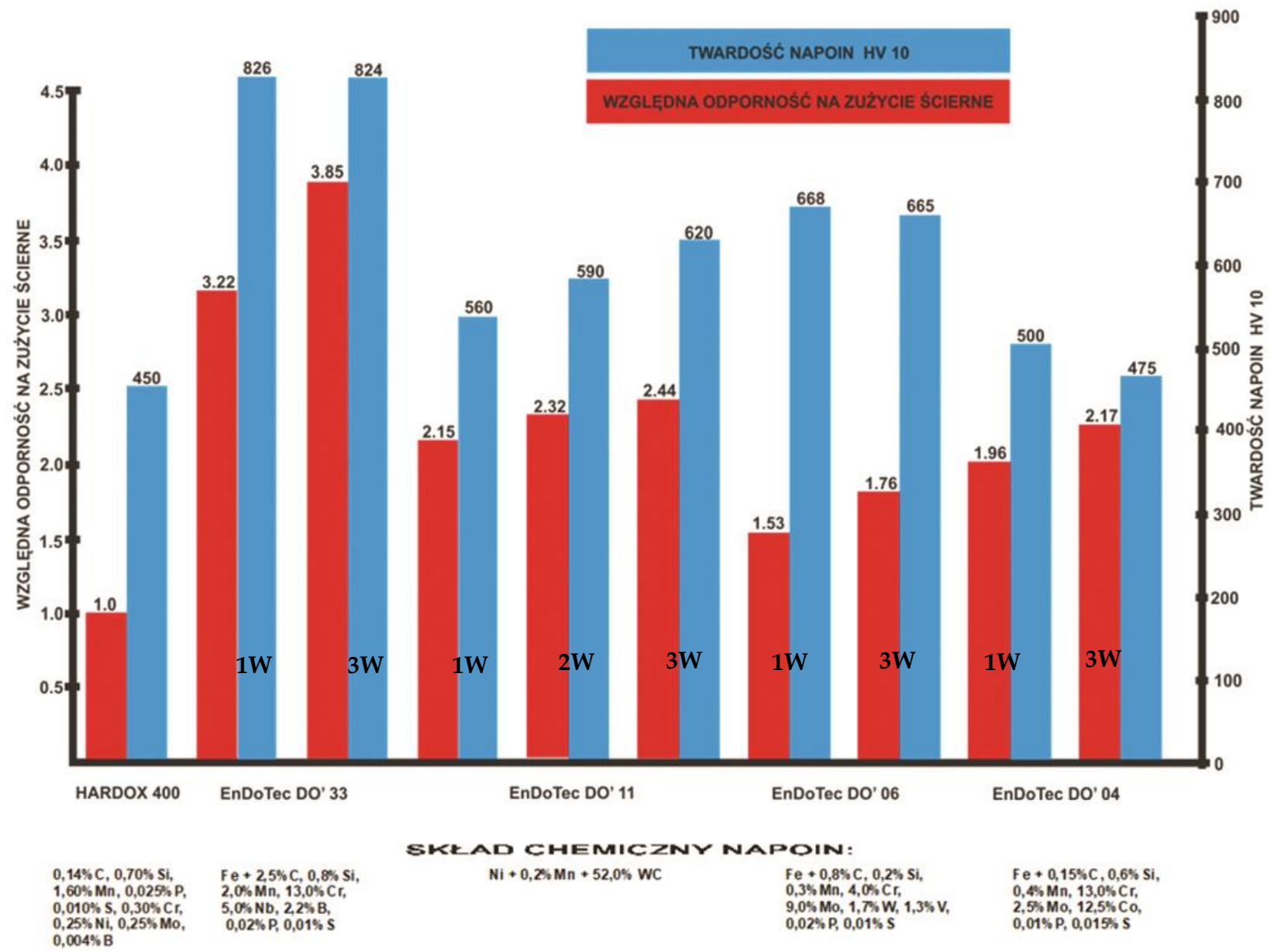

Fig. 3. The influence of chemical composition, hardness and number of beads $-\mathbf{W}$ of deposits of GMA surfaced using metalic powder cored wires on the ceramic-metal abrasion wear resistance as per ASTM G 65 [2,9] 
Surfacing technologies, unlike thermal spraying processes, are characterized by accurate metallurgical fusion of the surfaced layer (padding weld) with partially molten base metal, whose share in the padding weld's metal can be up to $60 \%$. The share of the substrate metal in the padding weld - U, is defined as the ratio of the cross-sectional area of the partially molten substrate metal - Fw to the total surface of the padding weld, i.e. the sum of the cross-sectional area of the excess weld metal - FN and the cross-sectional area of the partially molten substrate metal - Fw (Fig. 4):

$$
\mathrm{U}=\frac{\mathrm{F}_{\mathrm{w}}}{\mathrm{F}_{\mathrm{n}}+\mathrm{F}_{\mathrm{w}}} \times 100 \%
$$

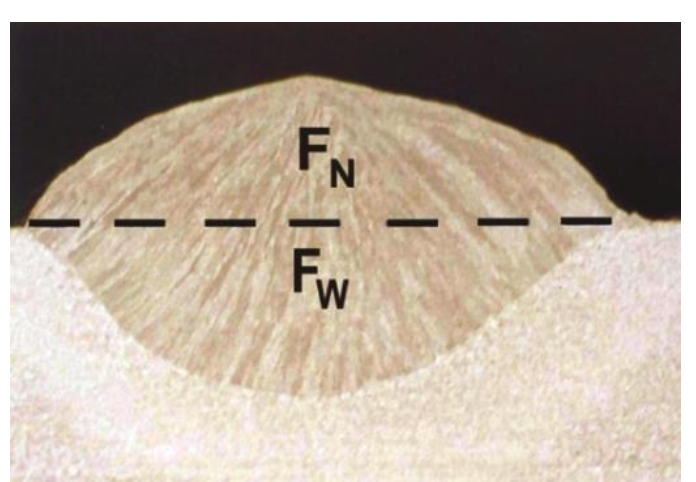

Fig. 4. Cross section of the single deposit bead GMA 1,2 mm dia. solid wire surfaced on S355 steel plate 10,0 mm thick; dilution of weld metal approx. $44 \%$ [9]

A much more accurate, but at the same time very costly and laborious way of determining the proportion of the substrate material in the padding weld $-\mathrm{U}$, is the analysis of the chemical composition of the weld deposit and the weld bead made on the substrate material with a specific chemical composition. The proportion of substrate material is then calculated as the ratio of the difference between the content of the basic alloy element (s) in the weld metal - PST\%, and the sum of the content of the basic alloy element (s) in the weld bead - PN \% and in the substrate metal - PMR \%, up to the sum of this element (these elements) in the weld deposit - PST \% and the substrate metal - PMR \%:

$$
U=\frac{P_{S T}-\left(P_{M R}+P_{N}\right)}{P_{S T}+P_{M R}} \times 100 \%
$$

In order to ensure optimal technological and economic conditions for the surfacing processes, one should strive to simultaneously ensure high efficiency of surfacing as well as the smallest possible share of base metal in the padding weld. This is difficult or often impossible to fulfill, because high efficiency of surfacing can only be obtained by increasing the linear energy of surfacing, which in turn leads to more intense melting of the substrate metal and its greater share in the padding weld.

The solution is the use of special surfacing techniques enabling accurate, synergic adjustment of the efficiency and quality of surfacing. Gas flame, electric arc, plasma or laser beam can be used a source of heat melting the additional material in surfacing processes. For friction surfacing processes - the kinetic energy of explosive detonation. Almost all metals and alloys as well as cermet and ceramic materials can be used as additional materials in surfacing processes (Table I, Fig. 5).

Before starting the coating process with the required operational properties, the type of the base material, its chemical composition and structural state should be precisely determined. This is especially important in the case of repair or regeneration of a structure that has been working for several decades, because the material may have undergone structural changes due to operational loads and spontaneous aging.

If, in turn, coating application is an integral part of the product's production, then the chemical composition of the base material should be designed together with the coating material and the optimal, in given technical and economic conditions of the plant, technology of surfacing or thermal spraying. Even a further step is possible and the product can be designed so that it can be regenerated many times after a certain degree of wear $[9,10]$. It is a particularly recommended solution for the regeneration of rollers, road wheels, chute cones for blast furnaces, crusher hammers, cutting knives etc. An important advantage 
of the planned regeneration of machinery and equipment parts is that their durability can be increased many times, even more than 20 times, at a cost much lower than the cost of a new part.

Table I. Typical, basic materials used for layers deposited on working parts of machines and equipment by welding surfacing and hardfacing technology $[1,7 \div 18]$

\begin{tabular}{|c|c|c|}
\hline Material & Typical types of materials & Typical functional properties \\
\hline Metals and alloys & $\begin{array}{l}\text { Steels, nickel alloys, cobalt alloys, } \\
\text { aluminum alloys, copper alloys, zinc, } \\
\text { lead, nickel, cobalt, titanium, tungsten, } \\
\text { molybdenum, tantalum, vanadium }\end{array}$ & $\begin{array}{l}\text { high strength, impact strength, hardness, } \\
\text { abrasive and adhesive wear resistance, corrosion } \\
\text { resistance, heat resistance and creep resistance }\end{array}$ \\
\hline $\begin{array}{l}\text { Ceramic } \\
\text { materials }\end{array}$ & $\begin{array}{l}\text { Carbides W, Cr, Ti, Mo, Zr, Hf, V, Nb, } \\
\text { Ta, Si, B, nitrides Ti, V, Zr, Si, Nb, Hf, } \\
\text { Ta, W, Cr, Mo, borides Ti, Zr, } \\
\text { silicides Mo, W, oxides } \mathrm{Al}, \mathrm{Cr}, \mathrm{Ti}, \mathrm{Zr}, \mathrm{Si} \\
\text { or mixtures thereof }\end{array}$ & $\begin{array}{c}\text { high resistance to abrasive wear, corrosion, high } \\
\text { hardness, heat resistance, creep resistance, } \\
\text { electrical and thermal insulation }\end{array}$ \\
\hline Cermets & $\begin{array}{c}\text { Carbides, borides, silicides and oxides } \\
\text { in the matrix of pure metals }(\mathrm{Ni}, \mathrm{Co}, \mathrm{Al} \text {, } \\
\mathrm{Cu}, \mathrm{Ti} \text { ) or alloys, e.g. } \mathrm{Cr}-\mathrm{Ni}, \mathrm{Fe}-\mathrm{Cr}-\mathrm{Ni}- \\
\mathrm{B}-\mathrm{Si}\end{array}$ & $\begin{array}{c}\text { high resistance to abrasive wear, dynamic loads, } \\
\text { thermal shock, heat resistance, creep resistance, } \\
\text { corrosion resistance, low conductivity and } \\
\text { thermal expansion }\end{array}$ \\
\hline Plastics & $\begin{array}{l}\text { Polyethylene copolymers, polyvinyl, } \\
\text { polypropylene, polyester, nylon }\end{array}$ & $\begin{array}{c}\text { high corrosion resistance, very good electrical } \\
\text { and thermal insulation }\end{array}$ \\
\hline
\end{tabular}

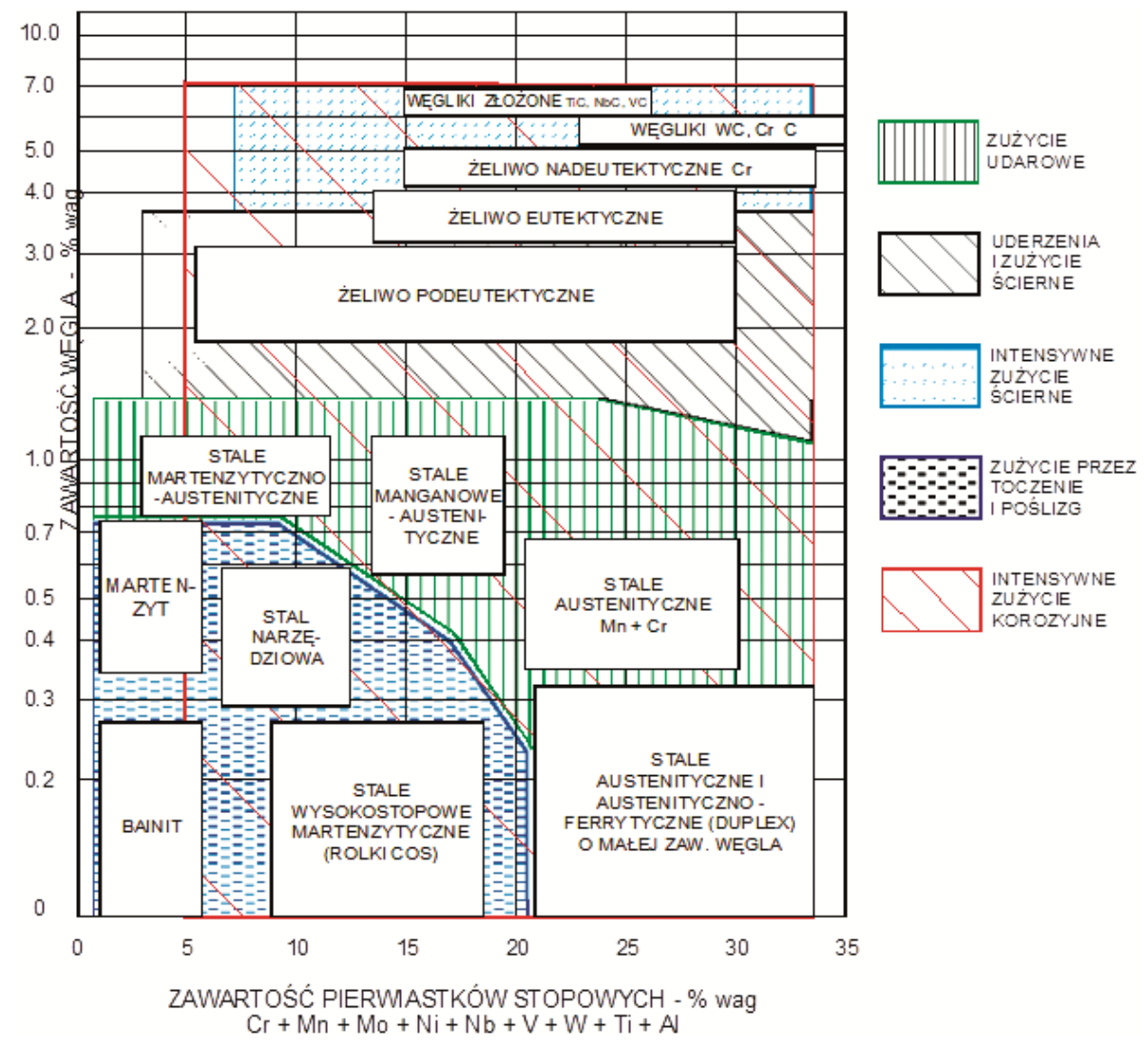

Fig. 5. Map of hardfacing, surfacing and thermal spraying applications of the iron matrix alloys [9]

The basic criteria for the selection of the welding process for applying coatings to a regenerated or manufactured object are as follows [9]:

1. the number and weight of regenerated or manufactured items,

2. the type of material of the object, its condition and weldability,

3. position of coating application and access to the surfacing or spraying area, 
4. required coating properties depending on the type of operating conditions: metal-metal, metal-mineral abrasion, dynamic load, corrosion, mechanical vibration, thermal load, etc.,

5. the required quality of the coating, its thickness, shape as well as the size and condition of the surface,

6. type, form and cost of the required additional materials,

7. required coating performance,

8. type of surfacing or spraying equipment available in the plant or cost of the new equipment.

Such a large number of often opposing factors makes it difficult to rationally choose the surfacing or thermal spraying process. The main ones among them are: quality and economy assurance.

The quality assurance, for a given product type and quality requirements, is mainly determined by the type of coating application process, the technique and technological conditions of coating application as well as the type of additional material.

Economy mainly includes the cost of additional materials, the cost of the device or its amortization, labor, energy costs and the lifetime of the regenerated product. Accurate knowledge of coating technology and the properties of additional materials, as well as their technical and economic characteristics, form the basis for a rational solution to the problem of regeneration, repair or manufacture of machinery and equipment. The examples described are illustrated in figures $6 \div 16$.

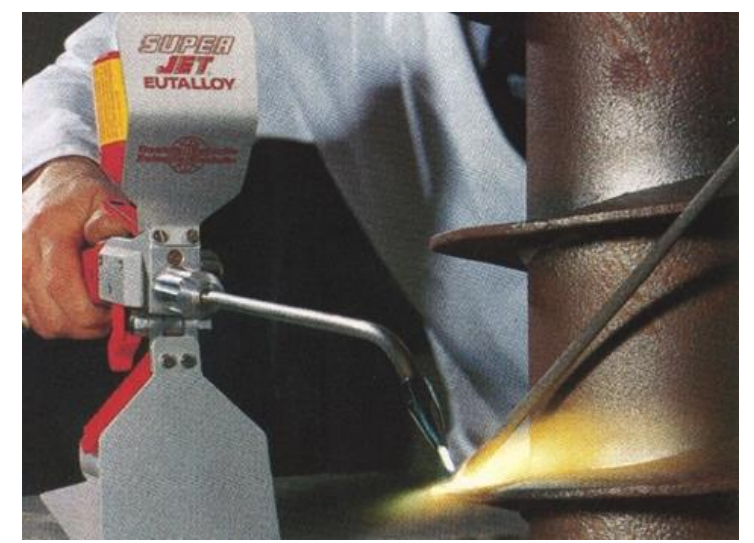

Fig. 6. A view of oxy-fuel powder surfacing of working edges of feeding screw with simultaneous feeding to the weld pool of the deposit a welding rod containing tungsten carbides in the Ni-Cr matrix. Weld metal dilution of the deposit can be controlled in the range of $0 \div 5 \%$ [2]

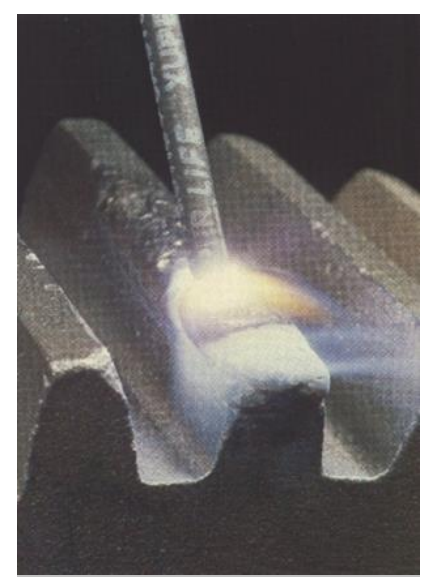

Fig. 7. A view of the repair MMA deposition process of working surface of a tooth gear, providing the metal-metal wear resistance deposit. Weld metal dilution of the deposit can be controlled in the range of $20 \div 60 \%$

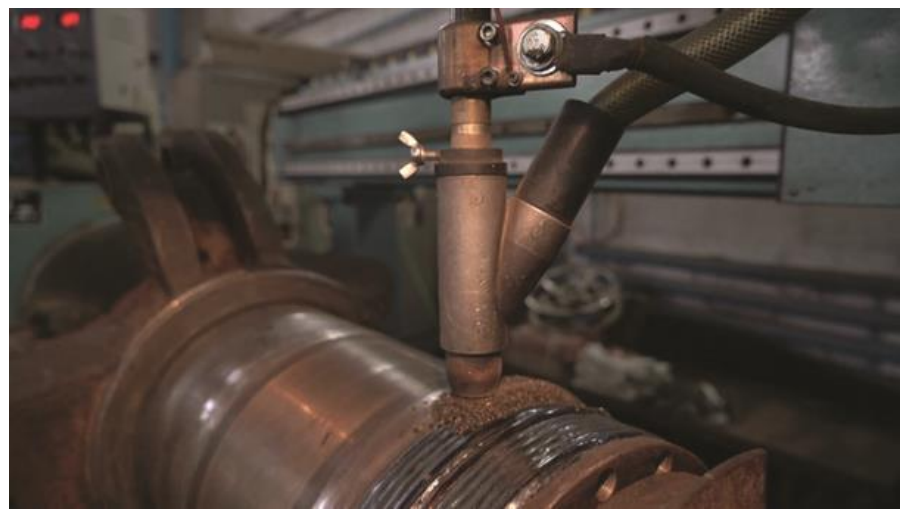

Fig. 8. A view of submerged arc surfacing process of the working surface of a steel mill roll. Weld metal dilution of the deposit can be controlled in the range of $25 \div 50 \%$ 


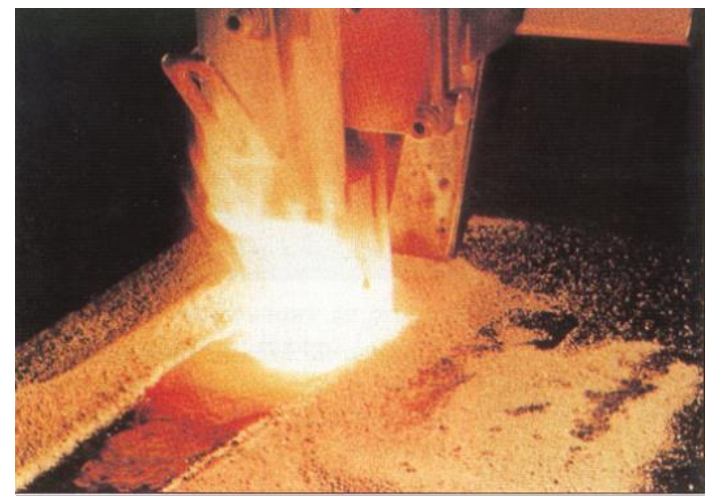

Fig. 9. A view of electroslag austenitic $(20 \% \mathrm{Cr}-10 \% \mathrm{Ni})$ solid strip surfacing process of the low alloy steel thick plate. Weld metal dilution of the deposit can be controlled in the range of $10 \div 30 \%$
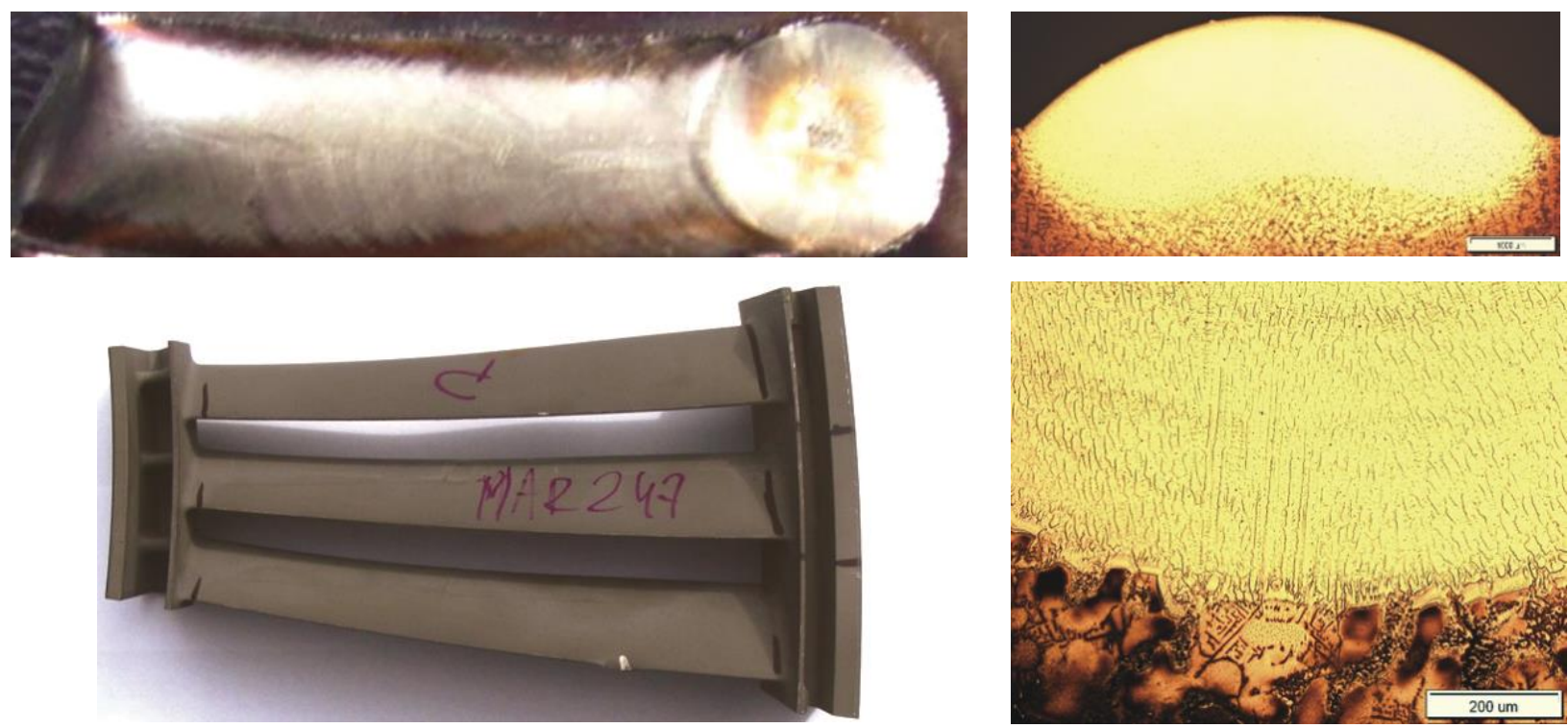

Fig. 10. A view of nickel superalloy MAR 247 vane segment casting and the macro and microstructure of the repair deposit of the surface defect GTA Inconel 65 wire deposited. Weld metal dilution of the deposit can be controlled in the range of $5 \div 15 \%$
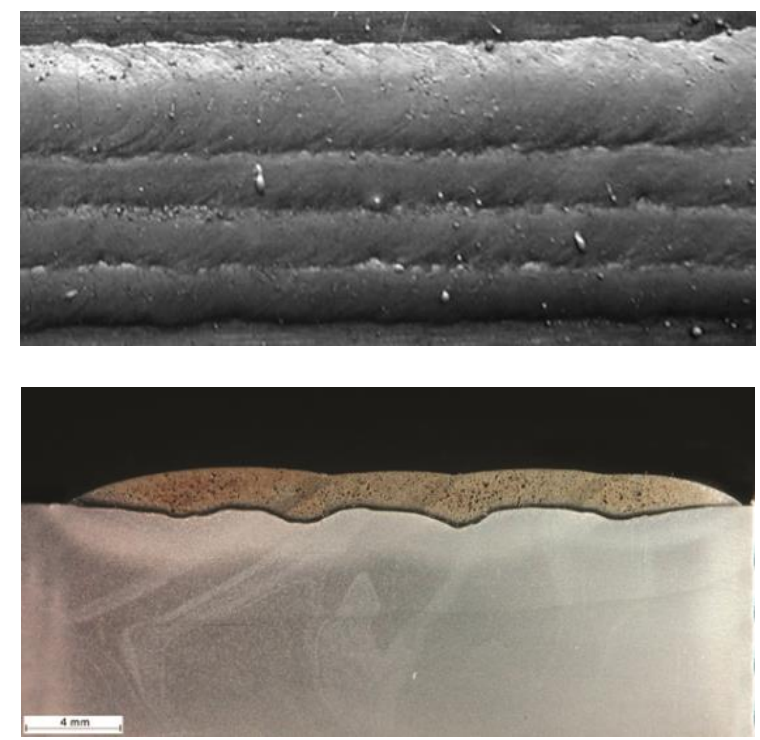

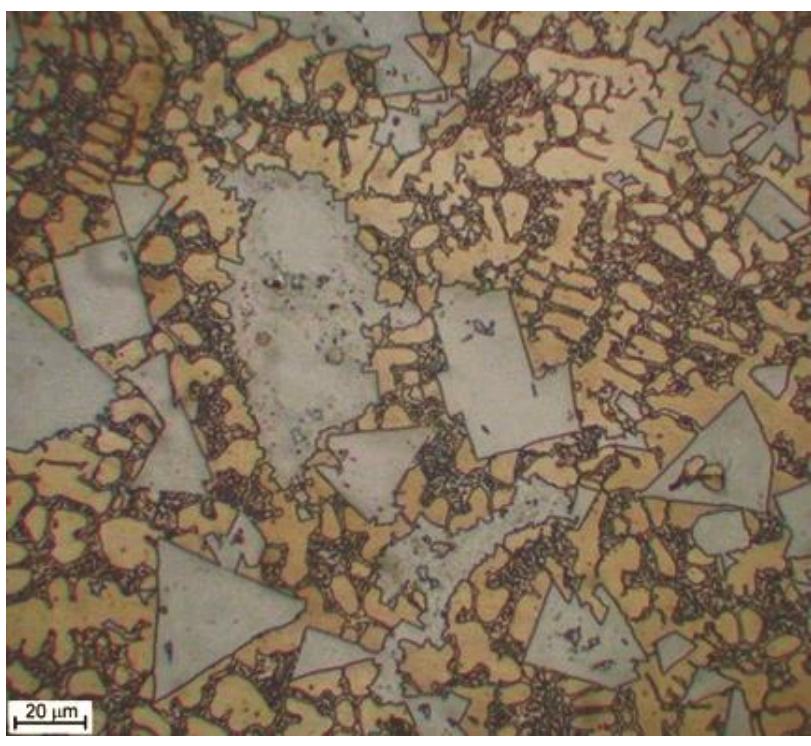

Fig. 11. A view of the Surface and macro and microstructure of the multilayer deposit automatic GMA powder metallic cored wire EnDoTec DO*611 ( Ni + 54\% WC0 surfaced on the S355 steel plate. Weld metal dilution of the deposit is $18,4 \%$ 

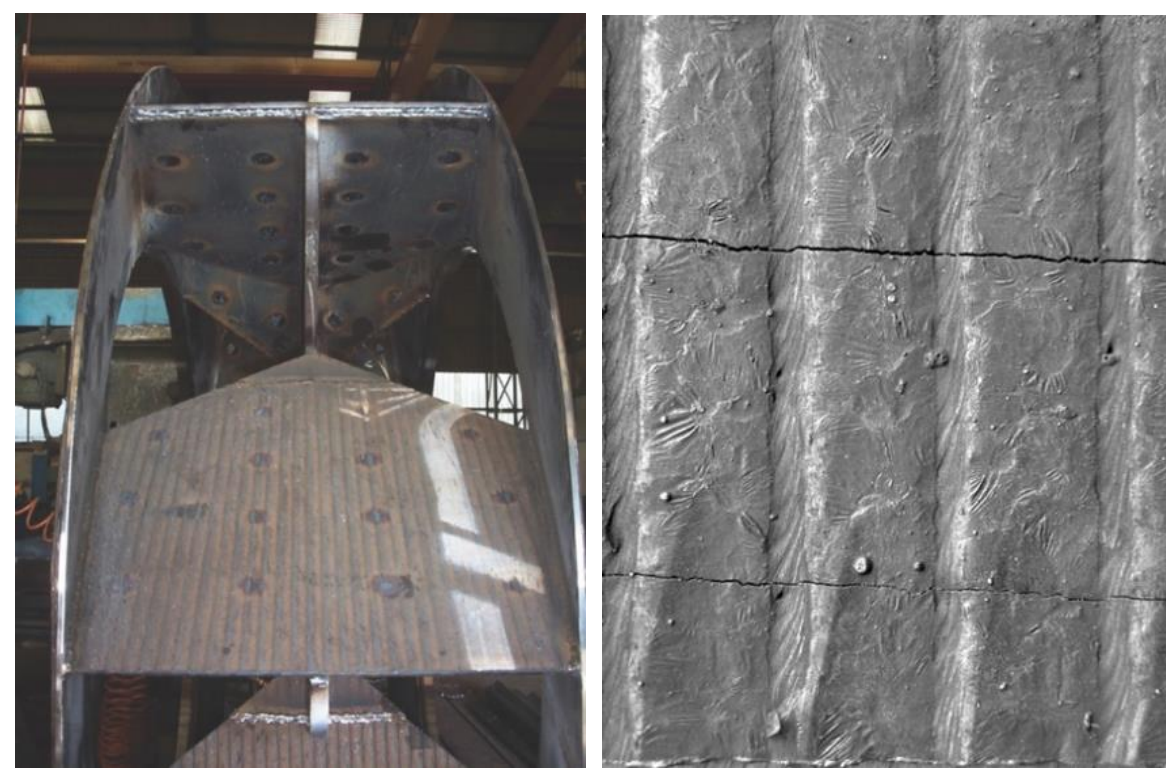

Fig. 12. A view of the blades of the exhaust fan system of steel mill fumes due to rolling processes; the blades are covered by wear plates CDP 4666 - 4666DP0805, providing high erosion, abrasion and corrosion resistance, attached to the blades by spot welds. The wear plates hardfaced on a robotized stand using self-shield wire TeroMatec 4666

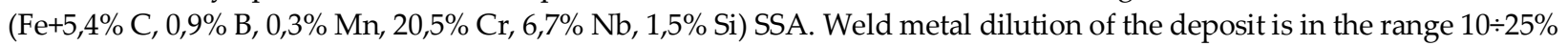
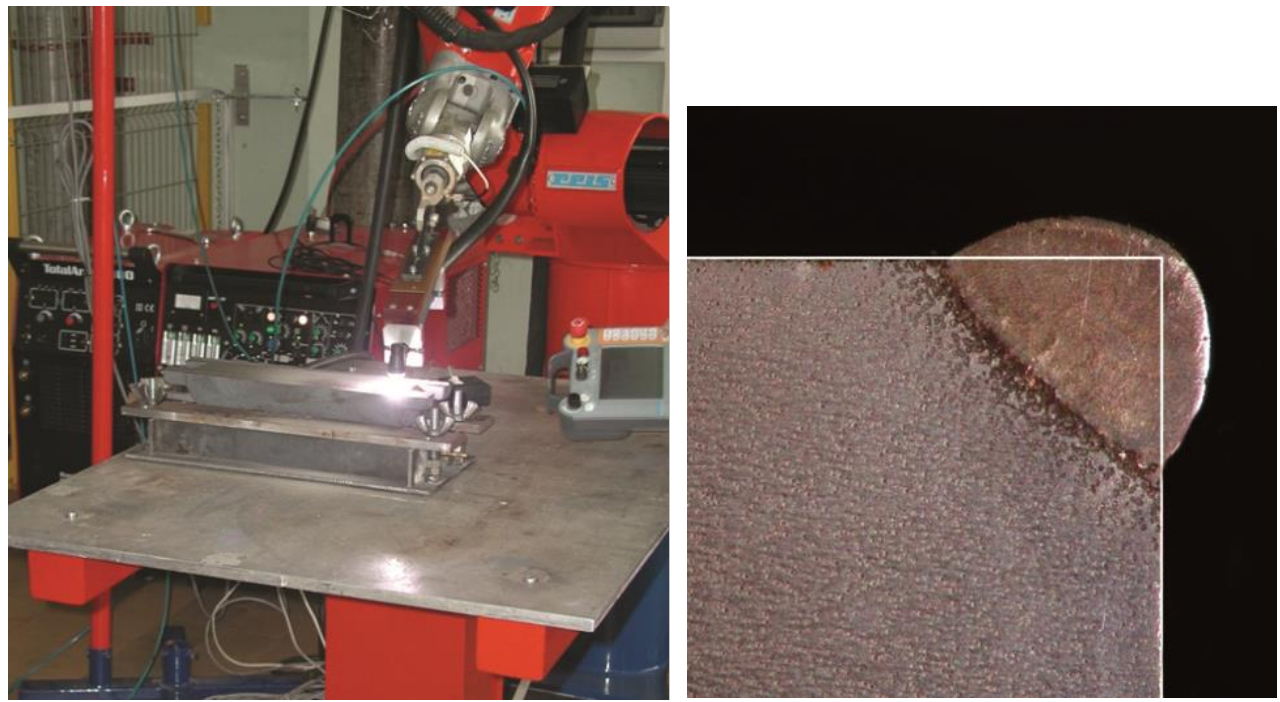

Fig. 13. A view of the powder plasma transferred arc cladding of the defected area of the spheroidal cast iron casting and a macrostructure of the edge PTA powder deposit of the spheroidal cast iron glass die. Weld metal dilution of the deposit can be controlled in the range of $5 \div 10 \%$ [17]

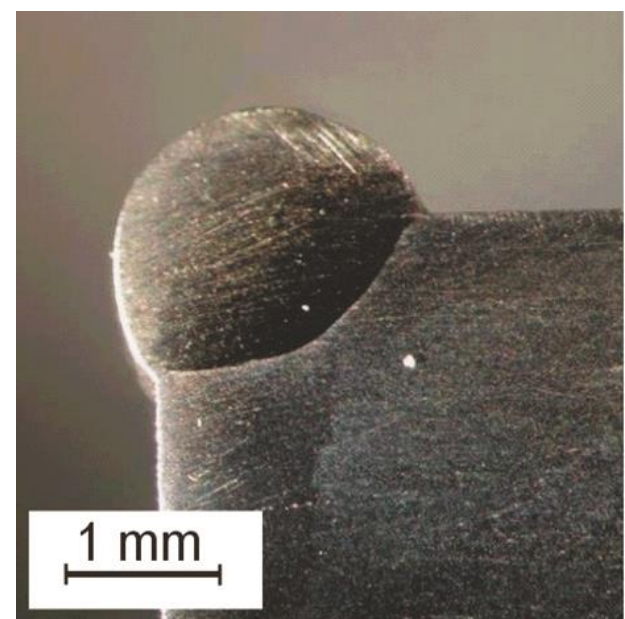

Fig. 14. The deposit surfaced by HPDL laser metallic powder cored wire dia. 1,0 mm type EnDOtec DO60 (Co + 1,0\% C, 0,5\% Si, 29\% $\mathrm{Cr}, 4,5 \% \mathrm{~W}, 3,0 \% \mathrm{Fe})$ on the working edge of a tool steel die X37CrMoV5-1 (WC). Laser deposition parameters: beam power 1,2 $\mathrm{kW}$, deposition speed $0,2 \mathrm{~m} / \mathrm{min}$. Weld metal dilution of the deposit can be controlled in the range of $2 \div 90 \%$ [17] 


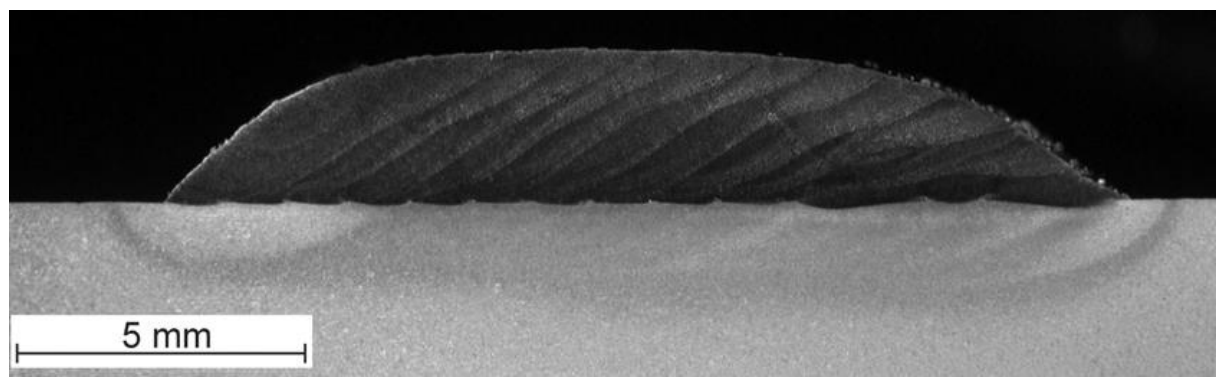

Fig. 15. Macrostructure of the 2,8 mm thick multilayer deposit, the cobalt matrix STELLITTE 6 metallic powder surfaced by HPDL ROFIN SINAR DL 020 on the tool steel WCL plate 15,0 mm thick. Laser deposition parameters: laser beam power $-1,2 \mathrm{~kW}$, deposition speed $-0,20 \mathrm{~m} / \mathrm{min}$, powder flow rate $-8,0 \mathrm{~g} / \mathrm{min}$, beads overlap - 30\%, laser focus dimensions $6,8 \times 1,8 \mathrm{~mm}$, focus length $-82,0 \mathrm{~mm}$, laser beam focused on the upper surface of deposited plate and shorted side oriented in direction of surfacing. Weld metal dilution of the deposit is 3,2\% [17]
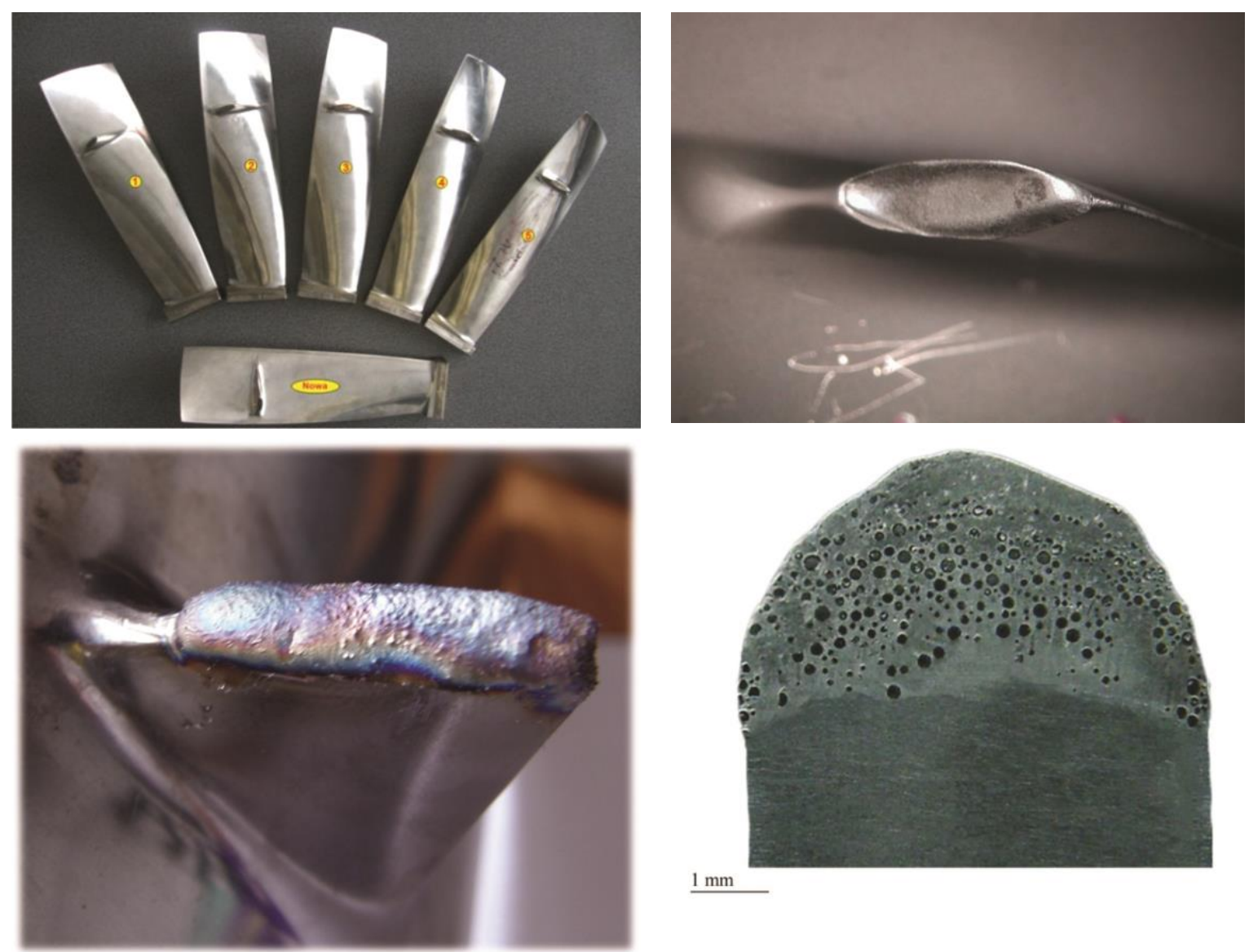

$1 \mathrm{~mm}$

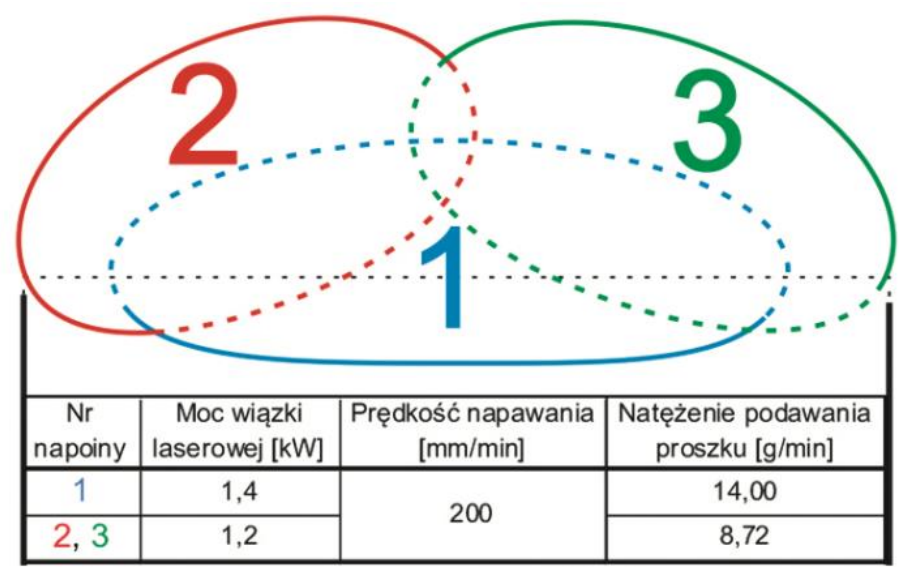

Fig. 16. A view of the titanium WT3-1 blades of AŁ-21 aircraft engine and the worn surface of the blade working shelf and the view of the repair laser deposit and its macrostructure. Repair HPDL ROFIN SINAR DL 020 diode laser three straight layers surfacing by cermetallic powder $50 \% \mathrm{Ti}+50 \% \mathrm{WC}$. Weld metal dilution of the deposit is $4,2 \%$ [17] 


\section{Summary}

Welding technologies for surface regeneration and modification are developed in the world industry, usually it's their their development or modification.

The parallel development of research into the functional properties of surface layers and modern welding materials provides the opportunity to develop production and/or regenerative surfacing technologies, ensuring higher utility properties and high economic efficiency, especially in the case of developing multiple regeneration technological conditions. Remanufacturing based on welding technologies often allows you to restore the nominal performance for several percent of the value of the regenerated item. In the context of the growing prices of materials showing resistance to various forms of wear, the possibility of making them a protective coating deposited on the core of cheaper material, opens the way to the wide application of welding methods of surface modification at the production stage.

Currently, welding technologies are a very important field of welding engineering, in which laser technologies of surfacing, alloying or remelting the surface layer have a particularly interesting position. The world industry sets higher and higher demands on the operating parameters of machinery and equipment parts, while also expecting the highest possible technical and economic effects. Thus, designers and technologists involved in the design and manufacture of modern machinery and equipment must take into account the issues of service life and economy. Meeting these conditions requires the use of modern computer-aided design methods and in-depth knowledge of material engineering. The very dynamic development of material engineering in recent years, including metallurgy and welding technologies, in particular laser technologies, ensures that designers of modern machine and device parts have increasingly better engineering materials at their disposal, ensuring previously unattainable properties.

\section{References}

[1] Burakowski T., Wierzchoń T.: Inżynieria powierzchni metali. Wyd. Naukowo-Techniczne, Warszawa 1995.

[2] ASTM G 65-00: Standard test method for measuring abrasion using the dray sand/rubber wheel apparatus.

[3] ASTM G 76-95: Standard test method for conducting erosion test by solid particle impingement using gas jets.

[4] ASTM G 99-95a: Standard Test Method for Wear Testing with a Pin-on-Disk Apparatus.

[5] Sposób badania przyczepności warstwy wierzchniej do podłoża, Patent - P, 341730, 23.03.2007.

[6] Sposób badania i oceny odporności na zużycie ścierne pod obciążeniem udarowym napawanych warstw wierzchnich, Patent nr 200880, 16.04.2009.

[7] Dobrzański L.A., Podstawy nauki o materiałach i metaloznawstwo, WNT, Warszawa 2002.

[8] Nowacki J. Spiekane metale i kompozyty z osnową metaliczna, WNT, Warszawa 2005.

[9] Klimpel A., Napawanie i natryskiwanie cieplne. Technologie, WNT, Warszawa 2000.

[10] Adamiec P., Dziubiński J., Regeneracja i wytwarzanie warstw wierzchnich elementów maszyn transportowych, Wydawnictwo Politechniki Śląskiej, Gliwice 1999.

[11] Coronado J. J., et al., The effects of welding processes on abrasive wear resistance for hardfacing deposits, Tribology International, 2009, Vol. 42(5), 745-749. [CrossRef]

[12] Buchely M. F., et al., The effect of microstructure on abrasive wear of hardfacing alloys, Wear, 2005, Vol. 259(1-6), 52-61. [CrossRef]

[13] Cao Y., Zhu S., Liang X., Wang W., Overlapping model of beads and curve fitting of bead section for rapid manufacturing by robotic MAG welding process, Robotics and computer-integrated manufacturing, 2011, Vol. 27(3), 641-645. [CrossRef]

[14] Sorour A.A., Chromik R.R., Brochu M., Tribology of a Fe-Cr-B-Based alloy coating fabricated by a controlled short-circuit MIG welding process, Metallography, Microstructure, and Analysis, 2013, Vol. 2(4), 223-233. [CrossRef]

[15] Labisz K., Tański T., Kremzer M., Janicki D., Effect of laser alloying on heat-treated light alloys, International Journal o Materials Research, 2017, Vol. 108(2), 126-132. [CrossRef]

[16] Janas D., Cabrero-Vilatela A., Bulmer J., Kurzepa L., Koziol K.K., Carbon nanotube wires for high-temperature performance, Carbon, 2013, Vol. 64, 305-314.

[17] Klimpel A., Technologie laserowe, Wydawnictwo Politechniki Śląskiej, Gliwice 2012.

[18] Klimpel A., Klimpel St. A., et al., Plasma welding repair procedure for turbine jet apparatus rings in aircraft engines, Welding International 2014, Vol. 28(6), 495-500. [CrossRef]

(C) 2019 by the authors. Submitted for possible open access publication under the terms and conditions of the Creative Commons Attribution (CC BY) license (http://creativecommons.org/licenses/by/4.0/). 